\title{
Minimal Invasive Extra-corporeal Circulation on End Stage Coronary Artery Disease Patients Undergoing Myocardial Revascularization
}

Ignazio Condello ( $\square$ ignicondello@hotmail.it)

Anthea Hospital https://orcid.org/0000-0003-1192-1908

Giuseppe Santarpino

Magna Graecia University of Catanzaro: Universita degli Studi Magna Graecia di Catanzaro

Francesco Bartolomucci

ASL BAT: Azienda Sanitaria Locale Barletta Andria Trani

Giovanni Valenti

ASL BAT: Azienda Sanitaria Locale Barletta Andria Trani

Nicola Di Bari

Azienda Ospedaliero-Universitaria Consorziale Policlinico di Bari

Marco Moscarelli

Anthea Hospital

Vincenza Vitobello

Anthea Hospital

Vera Triggiani

Anthea Hospital

Mario Gaudino

Weill Cornell Graduate School of Medical Sciences

Flavio Rimmaudo

Anthea Hospital

Giuseppe Speziale

Anthea Hospital

Giuseppe Nasso

Anthea Hospital

\section{Research Article}

Keywords: Minimal Invasive Extra-Corporeal Circulation, MiECC, End Stage Coronary Artery Disease, coronary artery bypass grafting

Posted Date: May 27th, 2021 
DOl: https://doi.org/10.21203/rs.3.rs-532121/v1

License: (c) (1) This work is licensed under a Creative Commons Attribution 4.0 International License. Read Full License 


\section{Abstract}

Background: Patients with coronary artery disease (CAD) undergoing myocardial revascularization, with concomitant heart failure defined by left ventricular ejection fraction (LVEF) lower than 35\%, constitute a population at risk of poor long-term prognosis and limited survival. The benefits of minimal invasive extracorporeal circulation (MiECC) on end stage coronary artery disease patients undergoing myocardial revascularization has not been described and evidenced by scientific studies.

Materials and Methods: In this single-centre control study of 60 end stage coronary artery disease patients undergoing isolated coronary artery bypass grafting. The patients was divided in two contemporary groups: in group (MiECC), $n=30$ coronary artery bypass grafting (CABG) was used MiECC, whereas, in group conventional extracorporeal circulation (cECC), n=30 CABG was used cECC.

Results: Procedures of Group MiECC reported (mean values) of a $\mathrm{DO}_{2 \mathrm{i}}$ of $305 \mathrm{~mL} / \mathrm{min} / \mathrm{m}^{2}$ in relation to $\mathrm{O}_{2} \mathrm{ER}_{\mathrm{i}} 21.5 \%$ vs a $\mathrm{DO}_{2 \mathrm{i}}$ of $288 \mathrm{~mL} / \mathrm{min} / \mathrm{m}^{2}$ in relation to $\mathrm{O}_{2} \mathrm{ER}_{\mathrm{i}} 25.6 \%$ was found in group MiECC vs cECC $(p=0.037)$. Lactate levels $>3 \mathrm{mmol} / \mathrm{L}$ were reported in 7 group MiECC patients vs 20 group cECC patients $(p=0.038)$, with blood glucose peak. Mean nadir $\mathrm{Hb}$ values during CPB were $9.7 \mathrm{~g} / \mathrm{dL}$ in group MiECC vs $7.8 \mathrm{~g} / \mathrm{dL}$ in group cECC $(p=0.044)$. Cl during CPB was $2.4 \mathrm{~L} / \mathrm{min} / \mathrm{m}^{2}$ in both groups. Total red blood cell administration was 8 units in group MiECC vs 21 units in group cECC $(p=0.022)$. A glycemic peak was recorded in 7 patients of group MiECC vs 20 patients of group cECC $(p=0.037)$.

Conclusion:The MiECC technique on end stage coronary artery disease was associated with a higher $\mathrm{DO}_{2 \mathrm{i}}$ compared to CECC. MiECC patients showed a significant reduction in red blood cells units administration, in peak intraoperative lactate levels, which correlated with better postoperative renal outcome and shorter length of stay.

\section{Introduction}

Patients with coronary artery disease (CAD) undergoing myocardial revascularization, with concomitant heart failure defined by left ventricular ejection fraction (LVEF) lower than $35 \%$, constitute a population at risk of poor long-term prognosis and limited survival [21]. Acute kidney injury (AKI) in this population frequently occur after cardiopulmonary bypass and the perioperative techniques and strategies selection could be crucial for the prevention.

The management and monitoring of metabolic parameters during extra-corporeal circulation has gained widespread adoption over the years, particularly in relation to the target values of oxygen delivery $\left(\mathrm{DO}_{2}\right)>$ $262 \mathrm{~mL} / \mathrm{min} / \mathrm{m}^{2}$, carbon dioxide production $>5.3$, indexed oxygen extraction ratio $\left(\mathrm{O}_{2} \mathrm{ER}_{\mathrm{i}}\right)<25 \%[1-3]$, with average blood pressure values during cardiopulmonary bypass (CPB) of $50-70 \mathrm{mmHg}$. This has made it possible to reduce the incidence of postoperative acute kidney injury and to improve the management of aerobic vs anaerobic metabolism during cardiac surgery procedures. At the same time, 
minimally invasive extra-corporeal circulation (MiECC) technologies have been developed and introduced into clinical practice [4].

The aim of this study was to compare MiECC vs conventional extra-corporeal circulation (CECC) in end stage coronary artery disease patients undergoing myocardial revascularization, in terms of superiority in relation to metabolic parameters (maximum $\mathrm{DO}_{2}$, lower $\mathrm{O}_{2} \mathrm{ER}_{\mathrm{i}}$ ), red blood cell (RBC) consumption, duration of mechanical ventilation and peak postoperative serum creatinine.

\section{Material And Methods}

\section{Population and study design}

Between February 2020 and May 2021, 60 patients aged $>75$ to 83 years with a mean EuroSCORE II of 9.1-9.5\% and left ventricular ejection fraction (LVEF) lower than $35 \%$ undergoing myocardial revascularization at our institution. A retrospective comparison was carried out in terms of maximum $\mathrm{DO}_{2}$ and $\mathrm{O}_{2} \mathrm{ER}_{\mathrm{i}}<25 \%$ for standard cardiac index value $2.4\left(\mathrm{l} / \mathrm{min} / \mathrm{m}^{2}\right)$. The patients was divided in two contemporary groups: in group "MiECC", $\mathrm{n}=30$ coronary artery bypass grafting (CABG) was used MiECC, whereas, in group "cECC", $n=30$ CABG was used cECC (Table 1). Metabolic management through blood gas analysis integrated with the use of a metabolic parameter monitoring system during CPB was adopted in both groups. 
Table 1

Preoperative characteristics.

\begin{tabular}{|lll|}
\hline & Group & Group \\
& MiECC & cECC \\
& $(\mathbf{n = 3 0})$ & $\mathbf{( n = 3 0 )}$
\end{tabular}

The study protocol was approved by the local ethics committee and all patients provided written informed consent to data treatment.

\section{Data collection}

Patients were selected according to the following criteria:

- Patients with coronary artery disease (CAD) undergoing myocardial revascularization, with concomitant heart failure and left ventricular ejection fraction (LVEF) lower than $35 \%$ and complete CPB and cardioplegic arrest had to be foreseen with an expected CPB duration $>90 \mathrm{~min}$.

- Patients were excluded if they presented abnormal plasma lactate levels ( $>2 \mathrm{mmol} / \mathrm{L}$ ) before entering CPB, liver failure, obesity, uncompensated diabetes, autoimmune disease, active infection, any immunosuppressive therapy, or coagulation disorder. Patients undergoing combined surgery (e.g. aortic valve replacement (AVR) + CABG, about 300 patients during the study period) or surgery with circulatory arrest or having preoperative hematocrit $(\mathrm{Hct})<27 \%$ were also excluded. 
The cardiac surgery procedures that were analyzed for this study were CABG $(n=100)$. Preoperative data included patient demographics, baseline serum creatinine, left ventricular ejection fraction, comorbidities (chronic obstructive pulmonary disease, previous cerebrovascular accident), baseline hemoglobin ( $\mathrm{Hb})$, EuroSCORE II and New York Heart Association functional class [1].

Perioperative data included type of operation, CPB duration, nadir body temperature during CPB, nadir hematocrit (Hct) and $\mathrm{Hb}$ value (measured at the start of CPB and every 20 min thereafter), nadir $\mathrm{DO}_{2}$, nadir $\mathrm{DO}_{2 \mathrm{i}} / \mathrm{O}_{2} \mathrm{ER}_{\mathrm{i}}$ ratio during $\mathrm{CPB}$, nadir cardiac index $(\mathrm{Cl})$, nadir $\mathrm{Cl} /$ mixed venous oxygen saturation $\left(\mathrm{SvO}_{2}\right)$, peak serum lactate and glucose during $\mathrm{CPB}$ and perioperative red blood cells administrations.

Postoperative data included peak serum creatinine, mechanical ventilation time and days spent in the intensive care unit (ICU).

The primary endpoints were: maximum $\mathrm{DO}_{2 \mathrm{i}}$ in relation to $\mathrm{O}_{2} \mathrm{ER}_{\mathrm{i}}$ during $\mathrm{CPB}$ compared between groups in terms of intraoperative lactate and glycemia trends. Secondary endpoints were: and total red blood cells consumption, peak postoperative serum creatinine level [5-7], mechanical ventilation time and length of ICU stay.

\section{Anesthetics and surgical procedures}

Patients were monitored with five-lead electrocardiography, a left radial artery catheter, capnography, pulse oximetry, and rectal/urine bladder temperature sensors. Transesophageal echocardiography was performed in all patients. Anticoagulant therapy consisted of heparin sodium before CPB at $300 \mathrm{IU} / \mathrm{kg}$ to give an activated clotting time of $>480 \mathrm{~s}$ (ACT PLUS Medtronic, Minneapolis, MN, USA); for antagonization of heparin, $0.5-0.75 \mathrm{mg}$ protamine was applied for every 100 heparin units. Anesthesia was induced with intravenous sufentanil $(0.5-1 \mu \mathrm{g} / \mathrm{kg})$ and midazolam $(0.08-0.2 \mathrm{mg} / \mathrm{kg})$, and tracheal intubation was facilitated with intravenous rocuronium $(0.6-1 \mathrm{mg} / \mathrm{kg})$. Anesthesia was maintained with propofol $(2-5 \mathrm{mg} / \mathrm{kg})$ and sufentanil $(0.5-2.0 \mu \mathrm{g} / \mathrm{kg})$, and the depth of anesthesia was monitored using bispectral index values (BIS XP, Aspect Medical System, Newton, MA, USA). The dosage of propofol was titrated to maintain bispectral index values between 40 and 60. AVR and CABG procedures were performed in median sternotomy with central cannulation, and surgical procedures were performed as routine by two surgeons. Concentrated red blood cells were transfused whenever $\mathrm{Hb}$ concentrations fell below $6 \mathrm{~g} / \mathrm{dL}$ during surgery or below $8 \mathrm{~g} / \mathrm{dL}$ during ICU stay. The goal of the hemoconcentration was to eliminate the excess of crystalloid administration.

\section{Cardiopulmonary bypass setting Group (MiECC)}

Closed circuit was performed with MiECC type III with Stöckert S5 heart-lung machine (LivaNova, London, UK) [4], whose design presents the characteristics of a volume management circuit (MiECTiS classification). A shunted venous soft-shell reservoir (Closed, Eurosets, Medolla, Italy) was used, the 
aortic root and pulmonary artery suction was managed in series venous return. Components (Biopassive Coating Phisio, LivaNova, London, UK) (Fig. 1): venous-arterial line diameter (3/8), venous bubble-trap (Sherlock, Eurosets), a centrifugal pump (Biomedicus BPX80, Medtronic, Eden Prairie, MN, USA), and a polypropylene fiber oxygenator (Alone, Eurosets). A bubble detection system was used to remove the air from the bubble trap and the circuit (Stockert, LivaNova). Circuit filling volume $500 \mathrm{~mL}$ crystalloid solution. $300 \mathrm{IU} / \mathrm{kg}$ of sodium heparin were administered, the activated clotting time prior to CPB was 501 $\mathrm{s}$, the cannulas were connected to the air-free circuit, and the bypass with a closed system was set up, the reference value of management of venous drainage was the central venous pressure, maintained around $5 \mathrm{mmHg}$ using urapidil as a vasodilator for higher values, or upon request of drainage by the surgeon, for lower values the Trendelenburg position was used $[3,4,8,9]$. All patients were treated with mild hypothermic $\mathrm{CPB}\left(34^{\circ} \mathrm{C}\right.$ to $\left.36^{\circ} \mathrm{C}\right)$. For the administration of myocardial protection, a closed circuit for cardioplegia with heat exchanger, with an infusion syringe pump in series and Saint Thomas solution with procaine were used and repeated every $30 \mathrm{~min}$. The Landing monitoring system (Eurosets, Medolla, Italy) was used for $\mathrm{DO}_{2}$ management during $\mathrm{CPB}$. In both groups, blood gas analyses were performed using alpha-stat management with a blood gas analyzer (GEM Premier 3000 IQM, Instrumentation Laboratory, Werfen Group IVD company, Munchen, Germany) set to measure at $37^{\circ} \mathrm{C}[10]$. On the basis of arterial blood data, we assessed the lowest Hct (percentage) on CPB; every 20 min, an arterial blood gas analysis, including blood glucose $(\mathrm{mg} / \mathrm{dL})$ and lactate $(\mathrm{mmol} / \mathrm{L})$ determination, was obtained. $\mathrm{An} \mathrm{Hb}$ value $<6 \mathrm{~g} / \mathrm{dL}$ during CPB was considered the trigger point for red blood cell transfusion. All patients received tranexamic acid according to routine protocol. Mean arterial pressure during CPB procedures was managed for values between $55-70 \mathrm{mmHg}$.

\section{Group (cECC)}

Open circuits with roller pumps (Admiral, Remo-well Eurosets, Medolla, Italy; Inspire 6 F, LivaNova, London, UK) were used for CPB. Pericardial blood was collected separately and could be processed or reinjected, if needed. The hard shell and softshell reservoir, oxygenating module and circuits were treated with phosphorylcholine (Agile Eurosets, Medolla, Italy; Phisio, LivaNova, London, UK). All patients were treated with mild hypothermic CPB $\left(34^{\circ} \mathrm{C}\right.$ to $\left.36^{\circ} \mathrm{C}\right)$; a volume of $1250 \mathrm{~mL}$ crystalloid Ringer acetate solution was used for priming. The surgical procedures selected for this study do not justify the use of moderate hypothermia by falling below $34^{\circ} \mathrm{C}$. For this reason, in the event of an initial increase in anaerobic metabolism, the first compensation approach was not to lower the temperature but possibly liquids or red blood cells were integrated.

The hardware consisted of a Stöckert S5 heart-lung machine and a Stöckert Heater Cooler System $3 T$ (LivaNova, London, UK) and the same cannulae were employed in both groups. For the administration of myocardial protection, a closed circuit for cardioplegia with heat exchanger, with an infusion syringe pump in series and Saint Thomas solution with procaine were used and repeated every $30 \mathrm{~min}$. The Landing monitoring system (Eurosets, Medolla, Italy) was used for $\mathrm{DO}_{2}$ management during CPB. In both groups, blood gas analyses were performed using alpha-stat management with a blood gas analyzer 
(GEM Premier 3000 IQM, Instrumentation Laboratory, Werfen Group IVD company, Munchen, Germany) set to measure at $37^{\circ} \mathrm{C}[10]$. On the basis of arterial blood data, we assessed the lowest Hct (percentage) on CPB; every $20 \mathrm{~min}$, an arterial blood gas analysis, including blood glucose $(\mathrm{mg} / \mathrm{dL})$ and lactate (mmol/L) determination, was obtained. An $\mathrm{Hb}$ value $<6 \mathrm{~g} / \mathrm{dL}$ during CPB was considered the trigger point for red blood cell transfusion. All patients received tranexamic acid according to routine protocol. Mean arterial pressure during CPB procedures was managed for values between $55-70 \mathrm{mmHg}$. The management of mean arterial pressure the same in both groups.

\section{Results}

Demographic, preoperative and operative details of the patient population are shown in Tables 1 and 2 . There are no difference between groups in terms on preoperative characteristics; the patients are isolated CABG procedures with LVEF low than 35\% and assessed risk (Euroscore II 9.1-9.5\% respectively). 
Table 2

Operative data.

\begin{tabular}{|c|c|c|c|}
\hline & $\begin{array}{l}\text { Group } \\
\text { MiECC } \\
(n=30)\end{array}$ & $\begin{array}{l}\text { Group } \\
\text { cECC } \\
(n=30)\end{array}$ & p-value \\
\hline $\mathrm{CPB}$ time (min), mean $\pm \mathrm{SD}$ & $115 \pm 9.2$ & $110 \pm 6.17$ & 0.93 \\
\hline Aortic cross-clamp time (min), mean \pm SD & $71 \pm 4$ & $69 \pm 6$ & 0.83 \\
\hline Nadir temperature $\left({ }^{\circ} \mathrm{C}\right)$ during $\mathrm{CPB}$, mean $\pm \mathrm{SD}$ & $34.9 \pm 1.1$ & $34.7 \pm 2.1$ & 0.75 \\
\hline Nadir $\mathrm{Hb}$ value $(\mathrm{mg} / \mathrm{dL})$ during $\mathrm{CPB}$, mean $\pm \mathrm{SD}$ & $9.7 \pm 1.5$ & $7.8 \pm 1.2$ & 0.044 \\
\hline Nadir Hct (\%) during CPB, mean \pm SD & $29.8 \pm 0.3$ & $25.1 \pm 2.1$ & 0.043 \\
\hline Nadir $\mathrm{Hb}$ value $(\mathrm{mg} / \mathrm{dL})$ after $\mathrm{CPB}$, mean $\pm \mathrm{SD}$ & $9.4 \pm 0.1$ & $7.2 \pm 0.8$ & 0.044 \\
\hline Nadir Hct (\%) after CPB, mean \pm SD & $29.2 \pm 0.1$ & $24.3 \pm 0.9$ & 0.045 \\
\hline Nadir $\mathrm{DO}_{2 \mathrm{i}}\left(\mathrm{mL} / \mathrm{min} / \mathrm{m}^{2}\right)$ during $\mathrm{CPB}$, mean $\pm \mathrm{SD}$ & $305 \pm 9$ & $288 \pm 6$ & 0.037 \\
\hline $\mathrm{O}_{2} \mathrm{ER}_{\mathrm{i}}(\%)$ during $\mathrm{CPB}$, mean $\pm \mathrm{SD}$ & $20 \pm 1$ & $25 \pm 3$ & 0.0029 \\
\hline Nadir $\mathrm{Cl}\left(\mathrm{L} / \mathrm{min} / \mathrm{m}^{2}\right)$ during $\mathrm{CPB}$, mean $\pm \mathrm{SD}$ & $2.4 \pm 0.2$ & $2.4 \pm 0.1$ & 0.94 \\
\hline Nadir $\mathrm{SvO}_{2}(\%)$ & $81 \pm 2$ & $75 \pm 5$ & 0.038 \\
\hline Crystalloid solution (mL) & $328 \pm 41$ & $727 \pm 57$ & 0.039 \\
\hline Red blood cells (Units) & 8 & 21 & 0.021 \\
\hline Red blood cells during (Units) in CPB & 3 & 10 & 0.023 \\
\hline Red blood cells (Units) Intensive Care Unit & 5 & 11 & 0.024 \\
\hline \multicolumn{4}{|c|}{$\begin{array}{l}\text { cECC, conventional extra-corporeal circulation; } \mathrm{MiECC} \text { minimally invasive extra-corporeal circulation; } \\
\mathrm{Cl} \text {, cardiac index; } \mathrm{CPB} \text {, cardiopulmonary bypass; } \mathrm{DO}_{2 i} \text {, indexed oxygen delivery; } \mathrm{Hb} \text {, hemoglobin; } \mathrm{Hct} \text {, } \\
\text { hematocrit; } \mathrm{O}_{2} \mathrm{ER}_{\mathrm{i}} \text {, indexed oxygen extraction ratio; } \mathrm{SD} \text {, standard deviation; } \mathrm{SvO}_{2} \text {, mixed venous } \\
\text { oxygen saturation. }\end{array}$} \\
\hline
\end{tabular}

Procedures of Group MiECC reported (mean values) of a $\mathrm{DO}_{2 i}$ of $305 \mathrm{~mL} / \mathrm{min} / \mathrm{m}^{2}$ in relation to $\mathrm{O}_{2} \mathrm{ER}_{\mathrm{i}}$ $21.5 \%$ vs a $\mathrm{DO}_{2 \mathrm{i}}$ of $288 \mathrm{~mL} / \mathrm{min} / \mathrm{m}^{2}$ in relation to $\mathrm{O}_{2} \mathrm{ER}_{\mathrm{i}} 25.6 \%$ was found in group MiECC vs cECC ( $\mathrm{p}=$ 0.037). Lactate levels $>3 \mathrm{mmol} / \mathrm{L}$ were reported in 7 group MiECC patients vs 20 group cECC patients ( $p$ $=0.038$ ), with blood glucose peak (Table 3) (. Mean nadir $\mathrm{Hb}$ values during CPB were $9.7 \mathrm{~g} / \mathrm{dL}$ in group MiECC vs $7.8 \mathrm{~g} / \mathrm{dL}$ in group cECC $(p=0.044)$. Cl during $C P B$ was $2.4 \mathrm{~L} / \mathrm{min} / \mathrm{m}^{2}$ in both groups. As for liquid administration, including the anesthesiologic infusions, $727 \mathrm{~mL}$ and $328 \mathrm{~mL}$ of crystalloid solution were given to group MiECC and cECC patients, respectively $(p=0.039)$ (Table 2). Total red blood cell administration was 8 units in group MiECC vs 21 units in group cECC $(p=0.022)$. A glycemic peak was 
recorded in 7 patients of group MiECC vs 20 patients of group cECC $(p=0.037)$. Patients with hyperlactatemia during CPB had a significant increase in serum creatinine value [6], a higher rate of prolonged mechanical ventilation and a longer ICU stay (Table 4). No patient underwent ultrafiltration during cardiopulmonary bypass.

Table 3

Analysis for peak blood lactate and $\mathrm{DO}_{2 \mathrm{i}}$ in relation to $\mathrm{O}_{2} \mathrm{ER}_{\mathrm{i}}$ on cardiopulmonary bypass for group MiECC and group cECC.

$\begin{array}{ll}\begin{array}{l}\text { No hyperlactatemia or } \\ \text { hyperglycemia }\end{array} & \begin{array}{l}\text { hyperlactatemia and } \\ \text { hyperglycemia }\end{array}\end{array}$

\section{Group (MiECC)}

No. patients 23

7

Peak blood lactate $(\mathrm{mmol} / \mathrm{L})$

$1.08 \pm 0.19$

$1.93 \pm 0.25$

on CPB

Mean $\mathrm{DO}_{2 \mathrm{i}}\left(\mathrm{mL} / \mathrm{min} / \mathrm{m}^{2}\right)$ on

$304 \pm 21$

$275 \pm 19$

CPB

Mean $\mathrm{O}_{2} \mathrm{ER}_{\mathrm{i}}(\%)$ on CPB

$20 \pm 3$

$38 \pm 4$

Blood glucose $(\mathrm{mg} / \mathrm{dL})$ on CPB

$129 \pm 9$

$205 \pm 11$

\section{Group (cECC)}

No. patients

10

20

Peak blood lactate $(\mathrm{mmol} / \mathrm{L})$ on CPB

$1.28 \pm 0.45$

$3.91 \pm 1.21$

Highest $\mathrm{DO}_{2 \mathrm{i}}\left(\mathrm{mL} / \mathrm{min} / \mathrm{m}^{2}\right)$ on $289 \pm 11$

$265 \pm 19$

CPB

Highest $\mathrm{O}_{2} \mathrm{ER}_{\mathrm{i}}$ (\%) on CPB

$25 \pm 3$

$33 \pm 4$

Blood glucose (mg/dL) on CPB $149 \pm 3$

$230 \pm 11$

CECC, conventional extra-corporeal circulation; $\mathrm{DO}_{2 \mathrm{i}}$, indexed oxygen delivery; $\mathrm{HG}$, hyperglycemia; $\mathrm{HL}$, hyperlactatemia; MiECC minimally invasive extra-corporeal circulation; $\mathrm{O}_{2} \mathrm{ER}_{\mathrm{i}}$, indexed oxygen extraction ratio. 
Table 4

Hyperlactatemia during cardiopulmonary bypass and postoperative outcome.

\begin{tabular}{|c|c|c|c|c|}
\hline & \multicolumn{2}{|c|}{$\begin{array}{l}\text { Group }(n=30) \\
\text { MiECC }\end{array}$} & \multicolumn{2}{|c|}{$\begin{array}{l}\text { Group }(n=30) \\
\text { cECC }\end{array}$} \\
\hline & $\begin{array}{l}\text { No HL } \\
(n=23)\end{array}$ & $\begin{array}{l}\mathrm{HL} \\
(\mathrm{n}=7)\end{array}$ & $\begin{array}{l}\text { No HL } \\
(n=10)\end{array}$ & $\begin{array}{l}H L \\
(n=20)\end{array}$ \\
\hline Peak serum creatinine $(\mathrm{mg} / \mathrm{dL})$ & $1.1 \pm 0.1$ & $1.4 \pm 0.5$ & $1.19 \pm 1.1$ & $1.7 \pm 1.5$ \\
\hline MV time (h) & $19.6 \pm 45$ & $55 \pm 31$ & $22.6 \pm 55$ & $52 \pm 49$ \\
\hline ICU stay (days) & $1.2 \pm 2.1$ & $5.2 \pm 4.9$ & $1.5 \pm 2.1$ & $6.1 \pm 2.9$ \\
\hline
\end{tabular}

\section{Discussion}

This retrospective study aimed at comparing two different CPB techniques (i.e. MiECC type III vs CECC) on end stage coronary artery disease patients undergoing myocardial revascularization in terms of $\mathrm{DO}_{2 i}$ values in relation to $\mathrm{O}_{2} \mathrm{ER}_{\mathrm{i}}$ with the same target $\mathrm{Cl}$, and of incidence of peak lactate and correlation with postoperative outcome. In particular, the type of ECC technique can influence either intraoperative $\mathrm{DO}_{2 \mathrm{i}}$ values for the same consumption of blood products or hemodilution. In other words, mean $\mathrm{DO}_{2} \mathrm{i}$ was higher in MiECC group compared to the $\mathrm{CECC}$ with a higher $\mathrm{Hg}$ and Hct although with less transfusions since the flow rate of the two circuits would have been the same. The reduced heamodiluition with MiECC can also explain the better obtained results in this group in terms of lower indexed oxygen ratio. The link between hyperlactatemia and hyperglycemia through the above mechanism was confirmed by Revelly et al. in 2005 [11] in an elegant study dealing with cardiogenic or septic shock. The role of adrenergic agonists in this setting is well defined: in cardiogenic shock, they are both endogenous or administered for cardiovascular therapy; in our model, they are endogenous in the majority of patients. None received epinephrine during CPB, and few received norepinephrine; however, unlike epinephrine, norepinephrine usually does not increase glucose production or induce an increase in plasma lactate concentration [1214]. The two mechanisms leading to hyperlactatemia in various clinical conditions are therefore (i) anaerobic metabolism due to a poor $\mathrm{DO}_{2}$, and (ii) excess lactate production due to glucose failing to enter the oxidative pathway and being degraded to lactate by the glycolytic pathway $[12,14,15]$. These mechanisms, if independently considered, lead to different acid-base balance conditions, the former being accompanied by metabolic acidosis and the latter not necessarily so. However, in the clinical conditions of this observational study, the acid-base balance is constantly maintained at a normal pH value by bicarbonate corrections applied by the perfusionist whenever the base excess starts decreasing. Therefore, we are unable to identify differences in hyperlactatemia related to different values of peak blood lactate. However, the evidence that only four patients demonstrated hyperlactatemia without 
hyperglycemia and that only patients with an hyperlactatemia-HG hyperglycemia syndrome had a significantly lower value of $\mathrm{DO}_{2}$ seems to confirm that, in our specific clinical environment,

hyperlactatemia and hyperglycemia are linked by the causative factor of a poor $\mathrm{DO}_{2}$, leading on one side to lactate production through the anaerobic pathway and on the other hand to a vicious cycle of lactate production due to the poor ability to use glucose through the aerobic pathway $[2,5,10,16]$. Reduced oxygen content in cases of acute anemia is usually compensated by reduced blood viscosity with increased blood flow in the microcirculation and by a compensatory increase in cardiac output [17]. This last mechanism may be impaired during $\mathrm{CPB}$, where pump flow is usually adjusted on the basis of the patient's body surface area and temperature, not the $\mathrm{Hb}$ value. On the basis of our data, the main

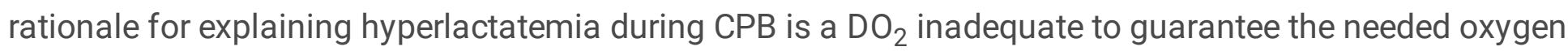
consumption of the patient.

In the present study, we investigated the role of potentially modifiable factors related to CPB surgery in determining postoperative hyperlactatemia (e.g. due to inadequate perfusion) and HG hyperglycemia [18]. Our results demonstrate, that a $\mathrm{DO}_{2 \mathrm{i}}<270 \mathrm{~mL} / \mathrm{min} / \mathrm{m}^{2}$ with $\mathrm{O}_{2} \mathrm{ER}_{\mathrm{i}}>35 \%$ and low $\mathrm{Cl}\left(<2.4 \mathrm{~L} / \mathrm{min} / \mathrm{m}^{2}\right)$ with $\mathrm{SvO}_{2}<65 \%$ during $\mathrm{CPB}$ are associated with hyperlactatemia and hyperglycemia and $\mathrm{DO}_{2 \mathrm{i}}>290$ $\mathrm{mL} / \mathrm{min} / \mathrm{m}^{2}$ with $\mathrm{O}_{2} \mathrm{ER}_{\mathrm{i}}<25 \%$ and $\mathrm{Cl}>2.4 \mathrm{~L} / \mathrm{min} / \mathrm{m}^{2}$ with $\mathrm{SvO}_{2}>75 \%$ during $\mathrm{CPB}$ are associated with a low incidence of hyperlactatemia $(\mathrm{HL})$ and hyperglycemia. Various preoperative factors or comorbidities may create the right environment for $\mathrm{HL}$ during $\mathrm{CPB}$. Age, female gender, congestive heart failure, low left ventricular ejection fraction, hypertension, atherosclerosis, diabetes, preoperative $\mathrm{Hb}$ value, redo or complex surgery, and emergency procedures were found to be risk factors for hyperlactatemia by Demers and coworkers [19], who reported an hyperlactatemia incidence of $18 \%$. Some of these factors were confirmed in our study, and other new factors were identified; however, our study population had a significantly shorter CPB duration and a lower degree of hemodilution during CPB. Given that both these factors seem to favor the onset of hyperlactatemia, the lower hyperlactatemia rate in our population is reasonably explained. The role of CPB duration in the determination of hyperlactatemia during CPB has been highlighted by other authors $[1,19,20]$. Moreover, the additional volume of crystalloid in the cECC group resulted in significant hemodilution as indicated by the mean hemoglobin values were more than 2 $\mathrm{g} / \mathrm{dL}$ greater for the MiECC group during bypass. This factor alone could have had a large impact on the other dependent variables including lactate levels and oxygen delivery.

\section{Study Limitations}

Several study limitations should be acknowledged. First, we do not know the microcirculation response for the higher $\mathrm{Hb}$ values in the MiECC group compared to CECC. Second, the absence of inflammatory markers (cytokines) that could affect postoperative outcome; also on the indexed oxygen delivery. Third, eight pre- and intraoperative factors were found to be significantly associated with peak blood lactate level during CPB at univariate analysis: age, isolated coronary operation, lowest pump flow/blood pressure, requirement of vasopressor or inotropic medications, lowest temperature, $\mathrm{Hct}$, and $\mathrm{DO}_{2 \mathrm{i}}$ were negatively correlated with peak blood lactate value during CPB, whereas CPB duration and peak blood 
glucose were positively correlated with peak blood lactate value during CPB. Despite this limitation, the samples were made homogeneous for the characteristics (Table 1). The Landing monitoring system was used for $\mathrm{DO}_{2}$ management during $\mathrm{CPB}$; however, we don't record duration of time $<280 \mathrm{ml} / \mathrm{min} / \mathrm{m}^{2}$.

Finally, the choice to use one or the other was based on the availability of the perfusionists with and without skills needed to manage the MiECC technique is another limitation of the study.

\section{Conclusion}

The end stage coronary artery disease patients undergoing myocardial revascularization with the MiECC technique had a higher $\mathrm{DO}_{2 \mathrm{i}}$ in relation to $\mathrm{O}_{2} \mathrm{ER}_{\mathrm{i}} 20-25 \%$ compared to patients operated on with the $\mathrm{CECC}$ technique. MiECC patients showed a significant reduction in blood red cells units administration in the incidence of peak intraoperative lactate, which correlated with reduced postoperative serum creatinine values and shorter mechanical ventilation and ICU stay, as compared to CECC patients.

\section{List Of Abbreviations}

CAD, Patients with coronary artery disease; MiECC, Minimal invasive extracorporeal circulation; CECC, Conventional extracorporeal circulation; $\mathrm{DO}_{2}$, Indexed Oxygen delivery; $\mathrm{O}_{2} \mathrm{ER}_{\mathrm{i}}$, Indexed oxygen extraction ratio; CPB, Cardiopulmonary bypass; $\mathrm{Cl}$, Cardiac index; $\mathrm{ACT}$, Activated clotting time; Hct, Hematocrit; $\mathrm{Hb}$, Hemoglobin; $\mathrm{HI}$, hyperlactatemia; LVEF, left ventricular ejection fraction; CABG, Coronary artery bypass grafting; AVR, Aortic valve replacement.

\section{Declarations}

Ethics approval and consent to participate: The study was evaluated and approved by the institutional board for clinical trials, Anthea Hospital GVM Care\&Research (internal protocol; decision 2020 Feb) and Informed consent was obtained from all subjects involved in the study.

Consent for publication: All authors have read and agreed to the published version of the manuscript.

Availability of data and materials: The datasets used and analysed during the current study are available from the corresponding author on reasonable request.

Competing interests: None.

Funding: None.

Authors' contributions: I.C. participated in manuscript writing, revision and conception. G.S. writing the manuscript. F.B. and G.V. gives support in conception. N.D. and M.M. participated in conception and manuscript vision. V.V. and V.T. gives support in statistical analysis. M.G. and F.R. participated in support 
and supervision. G.S. participated in support and conception. G.N. participated in support, re-writing and revision. All authors read and approved the final manuscript.

Acknowledgements: None

\section{References}

[1] Ranucci M, Isgrò G, Romitti F, Mele S, Biagioli B, Giomarelli P. Anaerobic metabolism during cardiopulmonary bypass: the predictive value of carbon dioxide derived parameters. Ann Thorac Surg 2006;81:2189-2195.

[2] Ranucci M, De Toffol B, Isgrò G, Romitti F, Conti D, Vicentini M. Hyperlactatemia during cardiopulmonary bypass: determinants and impact on postoperative outcome. Crit Care 2006;10:R167.

[3] de Somer F, Mulholland JW, Bryan MR, Aloisio T, Van Nooten GJ, Ranucci M. $\mathrm{O}_{2}$ delivery and $\mathrm{CO}_{2}$ production during cardiopulmonary bypass as determinants of acute kidney injury: time for a goaldirected perfusion management? Crit Care 2011;15: R19.

[4] Anastasiadis K, Antonitsis P, Haidich AB, Argiriadou H, Deliopoulos A, Papakonstantinou C, et al. Use of minimal extracorporeal circulation improves outcome after heart surgery; a systematic review and metaanalysis of randomized controlled trials. Int J Cardiol 2013;164:158-69.

[5] Maillet JM, Le Besnerais P, Cantoni M, Nataf P, Ruffenach A, Lessana A, et al. Frequency, risk factors, and outcome of hyperlactatemia after cardiac surgery. Chest 2003;123:1361-1366.

[6] Mehta RL, Kellum JA, Shah SV, Molitoris BA, Ronco C, Warnock DG, et al. Acute Kidney Injury Network: a report of an initiative to improve outcomes in acute kidney injury. Crit Care 2007;11:R31.

[7] Mehta RH, Grab JD, O'Brien SM, Bridges CR, Gammie JS, Haan CK, et al. Bedside tool for predicting the risk of postoperative dialysis in patients undergoing cardiac surgery. Circulation 2006;114:2208-2216.

[8] Benedetto U, Angeloni E, Refice S, Capuano F, Goracci M, Roscitano A, et al. Is minimized extracorporeal circulation effective to reduce the need for red blood cell transfusion in coronary artery bypass grafting? Meta-analysis of randomized controlled trials. J Thorac Cardiovasc Surg 2009;138:1450-1453.

[9] Biancari F, Rimpilainen R. Meta-analysis of randomised trials comparing the effectiveness of miniaturised versus conventional cardiopulmonary bypass in adult cardiac. Heart 2009;95:964-969.

[10] Landow L. Splanchnic lactate production in cardiac surgery patients. Crit Care Med 1993;21:S84-91.

[11] Revelly JP, Tappy L, Martinez A, Bollmann M, Cayeux MC, Berger MM, et al. Lactate and glucose metabolism in severe sepsis and cardiogenic shock. Crit Care Med 2005;33:2235-2240. 
[12] Totaro R, Raper RF. Epinephrine induced lactic acidosis following cardiopulmonary bypass. Crit Care Med 1997;25:1693-1699.

[13] Rashkin MC, Bosken C, Baughman RP. Oxygen delivery in critically ill patients. Relationship to blood lactate and survival. Chest 1985;87:580-584.

[14] Ensinger H, Geisser W, Brinkmann A, Wachter U, Vogt J, Radermacher P, et al. Metabolic effects of norepinephrine and dobutamine in healthy volunteers. Shock 2002;18:495-500.

[15] Ranucci M, Isgrò G, Romitti F, Mele S, Biagioli B, Giomarelli P. Anaerobic metabolism during cardiopulmonary bypass: predictive value of carbon dioxide derived parameters. Ann Thorac Surg 2006;81:2189-2195.

[16] Boldt J, Piper S, Murray P, Lehmann A. Severe lactic acidosis after cardiac surgery: sign of perfusion deficits. J Cardiothorac Vasc Anesth 1999;13:220-224.

[17] Habib RH, Zacharias A, Schwann TA, Riordan CJ, Durham SJ, Shah A. Adverse effects of low hematocrit during cardiopulmonary bypass in the adult: should current practice be changed? J Thorac Cardiovasc Surg 2003;125:1438-1450.

[18] Raper RF, Cameron G, Walker D, Bovey CJ. Type B lactic acidosis following cardiopulmonary bypass. Crit Care Med 1997;25:46-51.

[19] Demers P, Elkouri S, Martineau R, Couturier A, Cartier R. Outcome with high blood lactate levels during cardiopulmonary bypass in adult cardiac surgery. Ann Thorac Surg 2000;70:2082-2086.

[20] Weil MH, Afifi AA. Experimental and clinical studies on lactate and pyruvate as indicators of the severity of acute circulatory failure (shock). Circulation 1970;41:989-1001.

[21] Szlapka M, Hetzer R, Ennker J, Hausmann H. Conventional cardiac surgery in patients with end-stage coronary artery disease: yesterday and today. Cardiovasc Diagn Ther. 2021;11(1):202-212. doi:10.21037/cdt-20-284

\section{Figures}




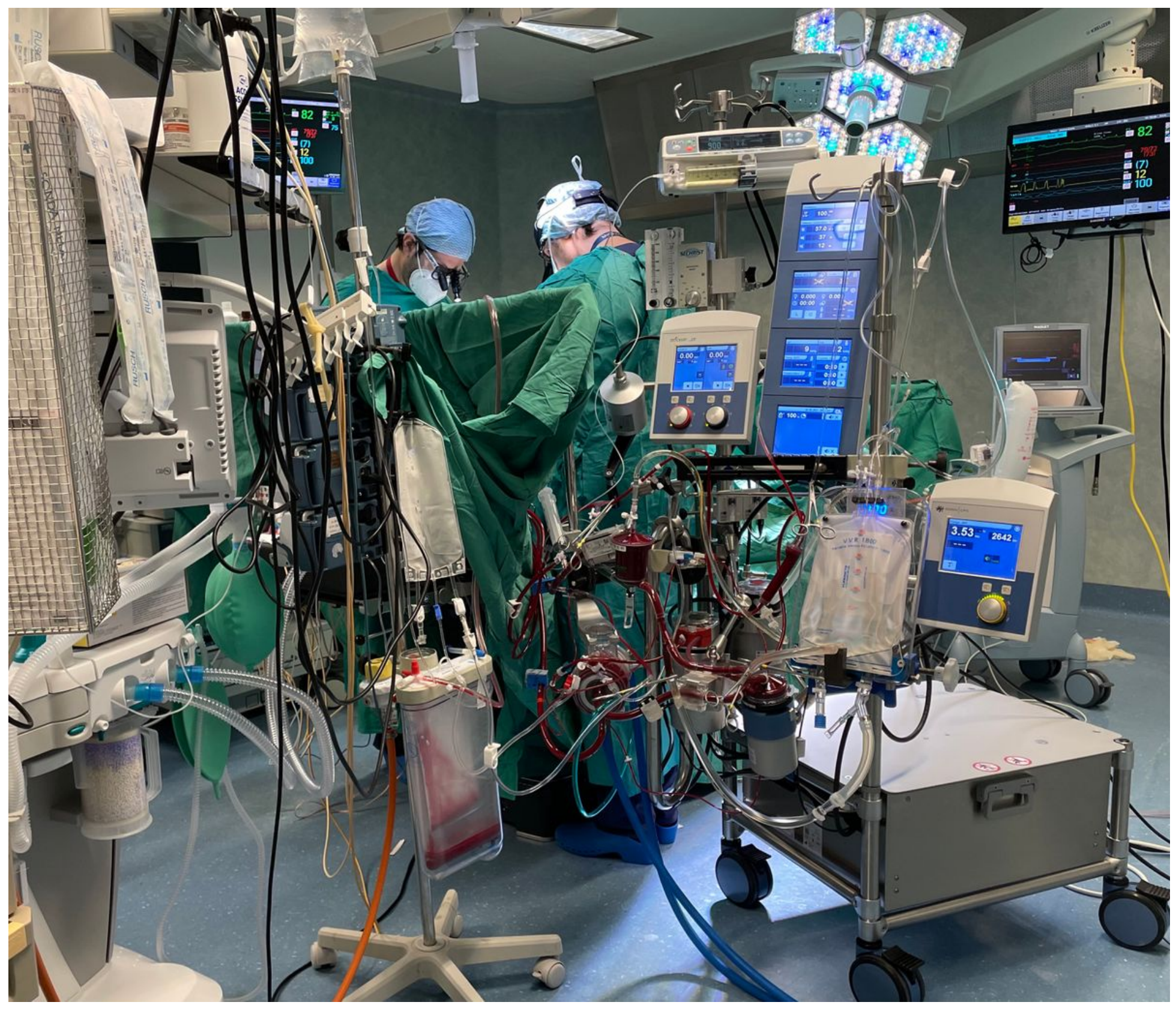

Figure 1

Minimal Invasive Extracorporeal Circulation (MiECC) during myocardial revascularization on end stage coronary artery disease patient. 